\title{
Inculcation of Higher Order Thinking Skills (HOTS) in Arabic Language Teaching at Malaysian Primary Schools
}

\author{
Mohd Yusri Kamarudin'1, Nik Mohd Rahimi Nik Yusoff'2, Hamidah Yamat@Ahmad², \\ Kamarulzaman Abdul Ghani ${ }^{3}$ \\ ${ }^{1}$ Ministry of Education, Putrajaya, Malaysia \\ ${ }^{2}$ Faculty of Education, National University of Malaysia, Bangi, Malaysia \\ ${ }^{3}$ Centre for Language Studies and Generate Development, University of Malaysia, Kelantan, Malaysia \\ Email:yusriqanun@yahoo.com,nik@ukm.edu.my,hamidah_yamat@ukm.edu.my, \\ Kamarulzaman@umk.edu.my
}

Received 11 January 2016; accepted 24 February 2016; published 29 February 2016

Copyright (C) 2016 by authors and Scientific Research Publishing Inc.

This work is licensed under the Creative Commons Attribution International License (CC BY).

http://creativecommons.org/licenses/by/4.0/

(c) (i) Open Access

\section{Abstract}

This study was aimed at identifying activities and teachers' role in inculcating Higher Order Thinking Skills (HOTS). A total of 30 teachers among main trainers of the Arabic language (j-Qaf) in primary schools in Malacca were selected as the respondents for the study. Data was collected via a questionnaire developed based on the checklist for teaching creativity and critical thinking (Teacher Checklist for Creative and Critical Thinking Instruction-TC-C2TI) and analysed for frequency, percentage, and mean. Findings have shown that the teachers provide support for exploration activities and conduct experiments among their students. Support is often given by providing opportunities for the students to think, learn, and study.

\section{Keywords}

Inculcation, Thinking Skills, Exploration and Experiments, Teaching Language

\section{Introduction}

Malaysia has given high priority to the development of education since independence in 1957. The country through the Ministry of Education (MOE) is committed to develop an educational system and student thinking skills since the 1980s. This is evident through the implementation of teaching of thinking skills such as the Cognitive Research Trust (CoRT), which was intended to promote students' thinking (Bono, 1991). Other thinking 
skills-based programmes have also been introduced, such as Accelerated Learning, Optimal Learning, and Six Thinking Hats, which are applied either in schools or universities. In the late 1990s, the MOE moved further with the inculcation of Creative and Critical Thinking Skills (CCTS) in the curriculum for all Malaysian students attending school (N. S. Rajendran, 2008).

The inculcation of CCTS may be seen across all curriculum, including the Primary School Arabic Curriculum. This is reflected in the Standard Document (DSK) for Arabic Language of the Standard Curriculum for Primary Schools (KSSR) and the Standard Document for Curriculum and Assessment (DSKP) (Curriculum Development Division, 2014) as follows:

$$
\text { ينم اختبار الدحاور لتلاميذ المدارس الابتدائية حسب الأشياء المتعلقة بهم والموجودة حولهم مثل عالم التناميذ في البيت و المدرسة والألألعاب }
$$

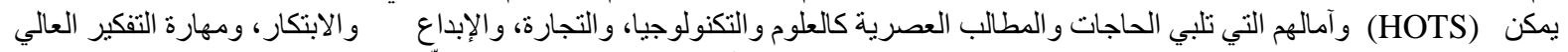

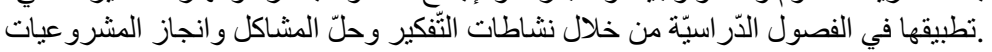

The choice of themes for primary school students include subject matters related to themselves and those around them, such as students' world at their homes and schools. These also include games and other ambitions to meet contemporary needs, such as science and technology, entrepreneurship, creativity and innovation, and higher-order thinking skills (HOTS). These all can be used in the classroom through activities of thinking and problem solving, as well as project-based learning.

The above statement shows that the content in the teaching and learning of basic Arabic language incorporates several skills, including higher-order thinking skills. It is therefore expected that by the end of the teaching and learning process of Arabic language at primary school level, students will not only acquire language but also related skills.

This goal is in line with Ryding's $(2012,2013)$ claim in his article "Critical Language and Critical Thinking Reframing Academic Arabic Programmes”, which posits that learning more than one language can improve student's cognitive ability in memorization, especially for short-term memory, mental balance, problem solving, abstract thinking, higher-order thinking skills and critical thinking, applications, and language awareness. Similarly, Ritchhart (2015) stated that students developed their language thinking skills by cultivating an atmosphere in which others were using the language. This is how the students acquire any new language, whether a mother tongue or foreign language.

Despite these goals and documentations, various problems arise when implementing thinking skills, such as teacher confusion (N. S. Rajendran, 2008), lack of training, and too many students in the class. These problems must be overcome in order to ensure the success of the government's desire to create students with global potential (Puteh, Ghazali, Tamyis, \& Aliza Ali, 2012). This may be due to the lack of a clear definition of HOTS. Both academicians and psychologists have different views of what HOTS refers to. As a result, there is no standard curriculum designed to promote thinking skills for application in classrooms (Onosko, 1992; Resnick, 1987). In fact, many teachers are still confused regarding the meaning of thinking, thinking skills, and the elements that make up these skills. This confusion may hinder teachers from inculcating these concepts in the teaching and learning process (N. S. Rajendran, 2008). Nevertheless, problems and constraints faced by teachers in the inculcation of HOTS may be overcome by planning, creativity, or programs at either the level of the teachers or at the ministry level (Limbach \& Waugh, 2010).

\section{Defining and Implementing Higher Order Thinking Skills (HOTS)}

Thinking is the process of using mind to seek meaning and understanding of things, make judgments and decisions, or solve problems (Curriculum Development Centre, 2002). According to Resnick (1987), Higher Order Thinking means "non-algorithmic". HOTS are defined as the potential use of the mind to deal with new challenges (Onosko \& Newmann, 1994). In this situation, one must understand, interpret, analyse and manipulate information. This is important because a question needs to be answered or a problem to be solved cannot be solved using routine approach. HOTS also require students to critically evaluate information, make inferences and make generalizations. They will also produce original communication, make predictions, suggest solutions, create and solve problems related to everyday life, evaluate ideas, express opinions, and make choices and decisions (N. S. Rajendran, 2001). In an attempt to define what pertains in HOTS, teachers must inculcate the concept at the level of applying, analysing, evaluating, and innovating based on Bloom's taxonomy revisions in their teaching (Curriculum Development Division, 2012; Examination Board, 2013). Meanwhile, in inculcating HOTS, Sulaiman (2003) found that teachers prioritize ten low-order thinking skills to be inculcated in teaching 
and learning of subject matter, which include thinking skills to gather information; comparing the differences; stating the reasons; arranging in order; explaining the concepts; expressing the results; creating relevance; effective description; and interpreting and creating the categories (Anderson et al., 2001; Sulaiman, 2003). The activities involving thinking skills in the classroom that are often used by teachers consist of three types of activities, namely discussion in groups, pairing activities, and questioning and answering. However, these three cognitive activities do not indicate higher-order thinking skills development process in teaching (Kamarudin \& Ghani, 2011). This is because teachers in Malaysia tend to focus on students mastering or knowing the basic contents of the subjects due to the exam oriented culture, rather than understanding and applying higher-order thinking skills (Sulaiman, 2003; Zailani \& Dahlan, 2005). In addition, teachers need to elicit student interest and talent to think at a higher level (N. S. Rajendran, 1998; Sternberg, 2013). Some of the teachers used a variety of approaches not only to motivate students in their thinking, but also to create their interest and excitement. Various activities may be conducted, such as debates, discussions, and role-play scenarios in order to achieve these goals (Hamza \& Griffith, 2006).

Students' acquisition and mastery of various Arabic language skills can only be guaranteed through the process of teaching and learning in schools with the guidance and continuous support by teachers (Abdul Wahab, 2014). The role of teachers in guiding and promoting students' cognitive level can help them learning the second language specifically. When the students learn a language, thinking skills also need to be applied so that they understand what they have learned. Likewise, when students think, they find that language is vital to convey what is in their mind. Thus, teaching activities that prioritize the role of cognitive and creativity may develop students' language potential at every level of learning so that they are able to use the learned language well. For examples, in conducting debates, students are expected to brainstorm; search for proof or evidence; and develop justifications that require them to synthesise, analyse, and make judgements based on facts. These are HOT skills that may be inculcated in such activities (Abdul Wahab, 2014; Pilus, 2011).

Traditionally in primary schools, to improve vocabulary and other lexical unit, students are taught according to the lists established on an ongoing basis. Almost every day, students are exposed to a number of vocabulary items, whether new vocabulary or vocabulary they have already learned. However, students still fail to remember the words; do not understand the meaning of the word, not just in choosing the words and so on. This phenomenon is considered to be the cause of the problem of language proficiency in Arabic, disrupting the smooth process of learning and mastering the language (Rahimi, Hussin, \& Normeza, 2014). Recognizing this, the Ministry of Education recommends inculcating HOTS, especially in teaching Arabic, by using a variety of techniques and activities to enhance the teaching and learning of Arabic language proficiency among students.

\section{Research Methodology}

The aim of this study was to identify the activities that the teachers carry out during the process of teaching Arabic language in increasing students' cognitive levels via HOTS. This descriptive study employed a survey research design using a set of questionnaires as the research tool. The questionnaire was developed based on the Teacher Checklist for Creative and Critical Thinking Instruction-TC-C2TI (Hamza \& Griffith, 2006). The study observed the teaching method and classroom climate of a group of teachers who contributed to the development of the environment for creative learning, creative thinking and problem-solving skills. The pilot study was conducted in national schools in Negeri Sembilan. 30 Arabic Language teachers were chosen via simple random sampling. Reliability analysis was carried out in order to determine the reliability of our questionnaire. Cronbach's Alpha was used to measure internal consistency of the questionnaire items. According to Piaw (2006), an alpha value of between 0.65 and 0.95 is considered as acceptable. The pilot study indicated that the coefficient for construct support exploration is at acceptable value of 0.83 .

In the current study, the researchers focused on the aspects of inculcating HOTS in exploration and experimentation activities. The current study was implemented in 30 national schools in Malacca. A total of 30 teachers teaching the Arabic subject for year 5 were selected. Therefore, the researchers have met the study respondents' selection criteria based on the profile of teachers in primary schools in three districts in Malacca-Alor Gajah, Melaka Tengah, and Jasin. They are also the (Higher Order Thinking Skills) presenters for Arabic subject-related dissemination courses. The main justification for the selection process is that those selected are the main trainers in Malacca and have been directly involved in developing the guidelines for HOTS teaching as required of Arabic Language teachers since 2013. A 5-point scale Likert was used to measure the frequency of 
activities and practices of HOTS as perceived by the teachers in their teaching. The scale used was: 1-Once in a while/Very rarely (less than $20 \%$ of the time), 2-Rarely (between $20 \%-40 \%$ of the time), 3-Sometimes (between $40 \%-60 \%$ of the time), 4 -Usually (between $60 \%-80 \%$ of the time), and 5-Always (more than $80 \%$ of the time). Meanwhile, the interpretation of the mean score, with reference to Abdul Ghafar (2003), spanned from very low (1.00 to 1.50 ), low (1.51 to 2.50 ), moderate (2.51 to 3.50), high (3.51 to 4.50 ) and very high at the score of 4.51 to 5.00 .

\section{Results and Discussion}

Table 1 shows the mean for teachers' inculcation of HOTS in exploration and experimentation activities. 8 items measured the inculcation of HOTS in exploration and experimentation. Out of 8 items, there was no very low level (1.00 to 1.50), low (1:51 to 2:50) and very high (4.51 to 5.00) mean scores. Only two items were at the moderate level (2.51 to 3.50), namely items 5 and 8 . Most of the means were at the high level (3.51 to 4.50), with a total of 6 items.

Item 1 and 6 have the highest mean level (i.e. 3.83). Item 1 measured teachers' inculcation of HOTS by providing opportunities for students to think, learn, and study. 14 (60\%) respondents stated always, and 4 (13.3\%) respondents stated that they usually create opportunities for students to think, learn and study during the sessions of teaching and learning. Meanwhile, the sixth item measured the use of a variety of approaches in problem solving and generating ideas. $20(66.7 \%)$ of the teachers stated always and $3(10 \%)$ of them perceived that they always encourage students to use a variety of approaches to solve problems and propose their own ideas.

The characteristics of inculcating HOTS through exploration, manipulation, experimentation, taking risks, tests, and modifying ideas had the lowest mean and at the moderate level of 3.30 for item 4. A total of 10 respondents (33.3\%) felt that they always inculcate, 2 respondents (6.7\%) reported that they usually inculcate, and only 5 (16.7\%) rarely inculcate HOTS through exploration.

Based on the findings of this study, children should not be seen as the passive recipients of knowledge; rather, they are the active producers in developing their own knowledge. Pestalozzi also recognized children's individual differences and emphasized the importance of self-activity (Puteh \& Ali, 2011). However, he did not rule out group activities, because through such activities, children would be able to cooperate with each other and this could motivate other children to work together. Implementation of Higher Order Thinking Skills (HOTS) that can make the process of teaching practice and learning a fun experience for students. Activities such as discussion collection, presentation and peer assessment can foster HOTS among students with the teacher's role is as a facilitator in the classroom (Tzuo, 2004). The role of teachers is to provide the learning context, as children's cognitive levels are tested in order to be involved in activities that require adjustment to correspond to their level of development (Mohd Razali \& Zaidatun, 2008; Moseley, 2005).

Active learning requires that students always perform meaningful learning experiences and always think about everything that can be done by them during the learning process (Keefe \& Jenkins, 2013). Through exploration and experimentation, various thought processes occur to compare differences, generate ideas, and make inferences. Students may perform exploration and experimentation and this is one way how to implement

Table 1. Descriptive statistics for teachers' support inculcation of HOTS in exploration and experimentation.

\begin{tabular}{|cc|}
\hline Item & Mean \\
\hline $\mathbf{1}$ & 3.83 \\
$\mathbf{2}$ & 3.70 \\
$\mathbf{3}$ & 3.57 \\
$\mathbf{4}$ & 3.30 \\
$\mathbf{5}$ & 3.50 \\
$\mathbf{6}$ & 3.83 \\
$\mathbf{7}$ & 3.77 \\
$\mathbf{8}$ & 3.33 \\
\hline
\end{tabular}


HOTS. In order to help students develop new concepts or knowledge, teachers need to consider the existing cognitive structure. When new information has been adjusted and absorbed to be used as part of their firm foundation, then something new about knowledge can be developed (Zainuddin \& Suardi, 2008). In other words, active learning will create or develop students' knowledge when they try to convey the meaning to their experience (Chang, 2005). Therefore, teachers are responsible to enable children to embrace external and existing knowledge and change them consciously while learning takes place (Carlson \& Wiedl, 2013).

Based on the Zone of Proximal Development (ZPD) theory by Vygotsky (1977), teachers play an important role in promoting students' cognitive and language levels. ZPD theory describes the zone between the level of real development and the potential development. The actual developmental stage begins from a child's ability to independently complete tasks. Meanwhile, the potential development only begins from the child's ability to complete tasks or solve problems with the help of adults (Robson, 2013). When entering the ZPD, the child is actually able to do it, but it would be optimal if adults or teachers who know better help them to achieve real progress. This theory also reflects the scaffolding theory. Scaffolding can be defined as providing a variety of assistance in the early stages of learning, and only then allowing them to take the responsibility for themselves in the learning and thinking process, after he or she has mastered the content of the subjects (Sabrin, 2010; Zwiers, 2006).

From the aspect of language, teachers are instrumental in developing students' language and speaking skills. According to Krashen \& Terrell (1996), the acquisition of language proficiency by an individual occurs indirectly and actively for the children aged two to six years old. In such situations in the classroom, a student learns the second language from the materials and exercises designed by the teachers. Teachers determine the type of materials and exercises based on the difficulty level appropriate for students (Angelis, 2007). In this situation, any material and strategy used may be successful if the learning situation favours the students, as well as not hindering the progress of the second language (Rahimi, Mahmod, \& Ghani, 2008). Indeed, an active role of language teachers is needed to ensure that the language students participate in the activities which encourage them to learn the language spontaneously (Ryding, 2012). Student-oriented learning would not be possible if teachers do not take the initiative to motivate language students to play their roles in the process of language acquisition (Mat \& Goh, 2010).

Findings indicate that the teachers themselves perceived that they only moderately and not highly practice the inculcation of HOTS. This is an alarming situation, because teachers play an important role in inculcating any values and skills, in this case HOTS. This is also true for the teaching of language. Language teachers should allow for and provide activities that involve exploration and experimentation, as students would acquire HOTS as they explore and experiment with language. For instance, when language teachers ask their students to find the meaning of new words from the context of the passage being read, students will make guesses or test their assumptions, while allowing them to explore and experiment and discover whether or not their guesses and assumptions are correct. This reflects the concept of scaffolding. Students need to be scaffolded until they reach the Zone of Proximal Development-ZPD (Vygotsky, 1977).

This is a limited study congruent with the procedures of a quantitative study. Firstly, in terms of methodology, the survey study was conducted via questionnaires distributed to Arabic Language teachers at primary schools specifically in Malacca. Besides limitations in terms of respondents, the researchers were also limited in terms of the study's focus. The researchers only had to focus on one component in the teaching of creativity lesson and critical thinking, which was exploration support and making experiments, without observing the other three components: Learning Environment Class Management, different idea support, and diverging thinking and learning content. It also did not involve Arabic Language learning strategies, class management, assessment processes, or other variables.

This study provides information about Arabic Language teachers' practices towards exploration support and conducting experiments in Malacca. Therefore, subsequent studies should be carried out to get more information on the topic at hand. Hence, a more detailed study on teachers' support for exploration and doing experiments should be carried out nationwide. A wide array of respondents may give a more accurate view of the research question. More detailed research methods such as interviews and direct observations can give more detailed information especially ones regarding teachers' conduct towards thinking skills and problems that might arise while executing it in the classroom. Other than that, the qualitative method can also be used to focus study exploration on subjects in depth, such as tests on Arabic teachers in SBT, cluster, or urban and suburban schools. 


\section{Conclusion}

This study on the practices of thinking skills among primary school teachers of Arabic language is important for Arabic language teachers in primary schools in Malaysia. The findings of this study should be considered in terms of the high level of teachers' support for exploration and experimentation activities, which may be implemented indirectly or by applying thinking skills. The implications of the study for curriculum policy makers and teachers themselves include directly emphasizing thinking skills for teaching and learning activities in teaching the Arabic language. The Arabic language curriculum should be improved by transforming HOTS explicitly in its syllabus. Findings have also indicated that Arabic teachers do not very highly practice exploration and experimentation activities that could inculcate HOTS. This implies that there is a need to encourage teachers to carry out such activities such as introducing language games, animation, other student-centered teaching aids, and other factors in order to increase students' interest in learning the Arabic language. This also implies that teachers should be given more knowledge and exposure on how to inculcate HOTS. Therefore it is recommended that teacher training programmes include HOTS inculcation. This preliminary study has also indicated that there is a need to explore further what teachers are doing in the classroom to see whether or not HOTS are being inculcated. This is significant to ensure that the government's effort to produce creative and critical thinkers will be successful over the long term.

\section{References}

Abdul Ghafar, M. N. (2003). Reka bentuk tinjauan soal selidik pendidikan. Skudai: Universiti Teknologi Malaysia.

Abdul Wahab, U. (2014). Penggunaan Penyusun Grafik Dalam Penguasaan Kolokasi Bahasa Arab. Kuala Lumpur: Universiti Malaya.

Anderson, L. W., Krathwohl, D. R., Airasian, P. W., Cruikshank, K. A., Mayer, R. E., Pintrich, P. R., Wittrock, M. C. et al. (2001). A Taxonomy for Learning, Teaching, and Assessing: A Revision of Bloom's Taxonomy of Educational Objectives. (L. W. Anderson \& D. R. Krathwohl, Eds.) (Complete E). Longman.

Carlson, J., \& Wiedl, K. (2013). Cognitive Education: Constructivist Perspectives on Schooling, Assessment, and Clinical Applications. Journal of Cognitive Education and Psychology, 12, 6-25.

http://www.ingentaconnect.com/content/springer/jcep/2013/00000012/00000001/art00003

http://dx.doi.org/10.1891/1945-8959.12.1.6

Chang, Y. (2005). The Pedagogical Content Knowledge of Teacher Educators : A Case Study In A Democratic Teacher Preparation Program. Athens, OH: Ohio University.

Curriculum Development Centre (2002). Kemahiran berfikir dalam pengajaran dan pembelajaran. Pusat Perkembangan Kurikulum, Kementerian.

Curriculum Development Division (2012). Buku Panduan Kemahiran Menaakul.

Curriculum Development Division (2014). Standard Document for Curriculum and Assessment.

De Angelis, G. (2007). Third or Additional Language Acquisition. Clevedon: Multilingual Matters.

Examination Board (2013). Pentaksiran Kemahiran Berfikir Aras Tinggi. Melaka: Lembaga Peperiksaan.

Hamza, M., \& Griffith, K. (2006). Fostering Problem-Solving \& Creative Thinking in the Classroom: Cultivating a Creative Mind. National Forum of Applied Educational Research Journal-Electronic, 19, 1-30.

http://www.nationalforum.com/Electronic\%20Journal\%20Volumes/Hamza,\%20Mohammed\%20Fostering\%20Problem\% 20Solving\%20\&\%20Creative\%20Thinking\%20in\%20the\%20Classroom.pdf

Kamarudin, M. Y., \& Ghani, K. A. (2011). Amalan Pentaksiran Bahasa Arab (PKSR) Sekolah Kebangsaan Di Negeri Sembilan. Prosiding Persidangan Antarabangsa Dan Pameran Penyelidikan Dalam Islam Dan Pendidikan Bahasa Arab (ICERIALE2011).

Keefe, J., \& Jenkins, J. (2013). Instruction and the Learning Environment (The School Leadership Library). New York: Routledge.

Krashen, S. D., \& Terrell, T. D. (1996). The Natural Approach: Language Acquisition in the Classroom (Revised ed.). England: Bloodaxe Books Ltd.

Limbach, B., \& Waugh, W. (2010). Developing Higher Level Thinking. Journal of Instructional Pedagogies, 3. http://www.aabri.com/manuscripts/09423.pdf

Mat, A. C., \& Goh, Y. (2010). Situasi pembelajaran bahasa asing di institut pengajian tinggi: Perbandingan antara Bahasa Arab, Bahasa Mandarin dan Bahasa Perancis. AJTLHE: ASEAN Journal of Teaching and Learning in Higher Education, 2, 9-21. http://journalarticle.ukm.my/1498/

Mohd Razali, N. A., \& Zaidatun, T. (2008). Rekabentuk sistem pembelajaran konsep nombor berasaskan pendekatan per- 
mainan yang menerapkan teori perkembangan kognitif kanak-kanak. Seminar Penyelidikan Pendidikan Pasca Ijazah, Universiti Teknologi Malaysia, Johor Bahru, 25-27 November 2008, 106-121.

Moseley, D. (2005). Frameworks for Thinking: A Handbook for Teaching and Learning. https://books.google.com.my/books?hl=en\&lr=\&id=s1D2IXoNZjwC\&oi=fnd\&pg=PP1\&dq=Frameworks+for+Thinking. $+\mathrm{A}+$ hand+book+for+teaching+and+learning.\&ots=9o5X0Ab1DZ\&sig=B7jF-LFkCFSPHPoXQqoaVuB727w\&redir_esc= $\mathrm{y} \# \mathrm{v}=$ onepage\&q=Frameworks\%20for\%20Thinking.\%20A\%20hand\%20book\%20for\%20teaching\%20and\%20learning.\&f =false

Onosko, J. (1992). Exploring the Thinking of Thoughtful Teachers. Educational Leadership, 49, 40-43. http://www.eric.ed.gov/ERICWebPortal/recordDetail?accno=EJ442790

Onosko, J. J., \& Newmann, F. M. (1994). Creating More Thoughtful Learning Environment. In J. Mangieri, \& C. C. Blocks (Eds.), Creating Powerful Thinking in Teachers and Students Diverse Perspectives (pp. 27-49). Forth Worth: Harcourt Brace College Publishers.

Piaw, C. Y. (2006). Kaedah Penyelidikan buku 2. Kuala Lumpur: McGraw-Hill (Malaysia) Sdn. Bhd.

Pilus, J. (2011). Maklum balas guru terhadap respon pelajar semasa pengajaran Bahasa Arab Tinggi: Satu kajian kes. Tesis Doktor Falsafah, Bangi: Universiti Kebangsaan Malaysia.

Puteh, S. N., \& Ali, A. (2011). Pendekatan bermain dalam pengajaran bahasa dan literasi bagi pendidikan prasekolah. Jurnal Pendidikan Bahasa Melayu, 1, 1-15.

Puteh, S. N., Ghazali, N. A., Tamyis, M. M., \& Aliza Ali. (2012). Keprihatinan guru bahasa melayu dalam melaksanakan kemahiran berfikir secara kritis dan kreatif. Jurnal Pendidikan Bahasa Melayu, 2, 19-31.

Rahimi, N. M., Hussin, Z., \& Normeza, W. (2014). Pembelajaran Kosa Kata Bahasa Arab Secara Aturan Kluster Semantik dan. Jurnal Teknologi (Social Sciences), 1, 33-38.

Rahimi, N. M., Mahmod, Z., \& Ghani, K. A. (2008). Motivasi Pembelajaran Kemahiran Mendengar Bahasa Arab dan Hubungannya dengan Pencapaian Pelajar. Jurnal Pendidikan, 33, 3-18.

Rajendran, N. S. (1998). Teaching Higher-Order Thinking Skills in Language Classrooms: The Need for Transmition of Teaching Practice.

Rajendran, N. S. (2001). Amalan Berdaya Fikir Pengajaran Pembelajaran Bahasa Melayu Dalam Bilik Darjah.

Rajendran, N. S. (2008). Teaching \& Acquiring Higher Order Thinking: Theory and Practice. Tanjong Malim: Universiti Pendidikan Sultan Idris.

Resnick, L. B. (1987). Education and Learning to Think. Washington DC: National Academy Press.

Ritchhart, R. (2015). Creating Cultures of Thinking: The 8 Forces We Must Master to Truly Transform Our Schools. San Fracisco, CA: Jossey-Bass.

Robson, S. (2013). The Analysing Children’s Creative Thinking Framework: Development of an Observation-Led Approach to Identifying and Analysing Young Children's Creative Thinking. British Educational Research Journal, 40, 121-134. http://dx.doi.org/10.1002/berj.3033

Ryding, K. C. (2012). Critical Language and Critical Thinking Reframing Academic Arabic Programs. In R. Bassiouney, \& G. Katz (Eds.), Arabic Language and Linguistics (pp. 189-200). Washington DC: Georgetown University Press.

Ryding, K. C. (2013). Teaching and Learning Arabic as a Foreign Language: A Guide for Teacher. Washington DC: Georgetown University Press.

Sabrin, M. (2010). The Need for an Islamic Pedagogy.

Sternberg, R. (2013). What Is Cognitive Education? Journal of Cognitive Education and Psychology, 12, 4-5. http://dx.doi.org/10.1891/1945-8959.12.1.4

Sulaiman, R. (2003). Pelaksanaan pendekatan pengajaran kemahiran berfikir dalam mata pelajaran sejarah: Satu kajian kes. Bangi: Universiti Kebangsaan Malaysia.

Tzuo, P.-W. (2004). The Nature of Teacher Control and Children's Freedom in a Child-Centered Classroom. PhD Thesis, Bloomington, IN: Indiana University.

Vygotsky, L. S. (1977). Mind in Society: The Development of Higher Psychological Processes (14th ed.). London: Havard University Press.

Zailani, M. A., \& Dahlan, H. B. A. M. (2005). Kesedaran Metakognitif Membaca dan Pencapaian Akademik Mata Pelajaran Bahasa. Jurnal Pendidikan, 25, 57-63.

Zainuddin, Z. A., \& Suardi, A. (2008). Keberkesanan Kaedah Konstruktivisme Dalam Pengajaran Dan Pembelajaran Matematik.

Zwiers, J. (2006). Integrating Academic Language, Thinking, and Content: Learning Scaffolds for Non-Native Speakers in the Middle Grades. Journal of English for Academic Purposes, 5, 317-332. http://dx.doi.org/10.1016/j.jeap.2006.08.005 


\section{Appendix A}

Teacher Checklist for Creative and Critical Thinking Instruction (TC C2TI)

Please rate yourself on the following attributes for teaching creative and critical thinking skills or using creative and critical thinking instructional strategies. Base your answers on the most recent three lessons that you have taught. Attach the lesson plan for each lesson. Remove all personal information from the lesson plan when you attach it. This information will not be shared by name or in the report in any way that can be traced back to you.

1) once in a while/very rarely (less than $20 \%$ of the time)

2) rarely (between $20 \%-40 \%$ of the time)

3) sometimes (between $40 \%-60 \%$ of the time)

4) often/usually (between $60 \%$ - $80 \%$ of the time)

5) always (more than $80 \%$ of the time)

\begin{tabular}{lrrrrrrr}
\hline \multicolumn{1}{c}{ SE = Support of Exploration and Experimentation } & & & \\
\hline 1 & Provided chances for students to think, learn, and discover & 1 & 2 & 3 & 4 & 5 \\
2 & Fostered self-initiated learning & 1 & 2 & 3 & 4 & 5 \\
3 & Helped students examine issues from different points of view & 1 & 2 & 3 & 4 & 5
\end{tabular}

